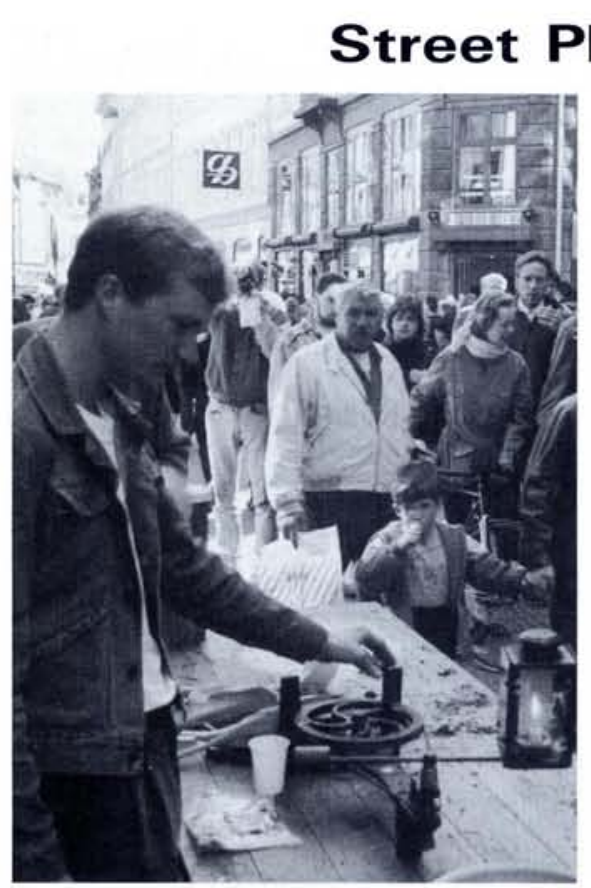

If you were not at EPS- 8 you missed a glimpse of street physics given by a group of students from Copenhagen that goes by the name "The Flying Circus". Competing with other street entertainers, the Circus lays on twice each year (the next show is in Copenhagen's shopping district on 12-13 October) a repertoire of 20 wonderful demonstrations of physics in action. The most popular experiment literally has kids turning in circles as they experience the gyroscope effect. Other items illustrate standing waves, the Bernouilli effect, the generation of enormous and remarkably stable smoke rings, magnetic levitation, diffraction patterns (of glue), fractals and the effects of cooling carnations to $70 \mathrm{~K}$.

With help from university staff, grants totally NKR 30000, and equipment donated by local companies, including four personal computers, the Circus working out of a room at the H.C. Orstedsinstituttet also puts on a rather serious five hour show to high school students who must write reports. Parties from primary schools come to see a light-hearted version from time-to-time.

The Flying Circus thinks it would be useful to swap information with other groups running, or interested in running, similar activities. Innovation is all important in show biz so the members, L. Hemmigsen, K. Pedersen, H. Busch, M. Svalgaard, S. Sorensen and M. Lindholmer, are very interested in new ideas as well. All communications to:

The Flying Circus, Physics Lab.,

H.C. Orstedsinstituttet,

Universitetsparken 5 ,

D-2100 Copenhagen 0.

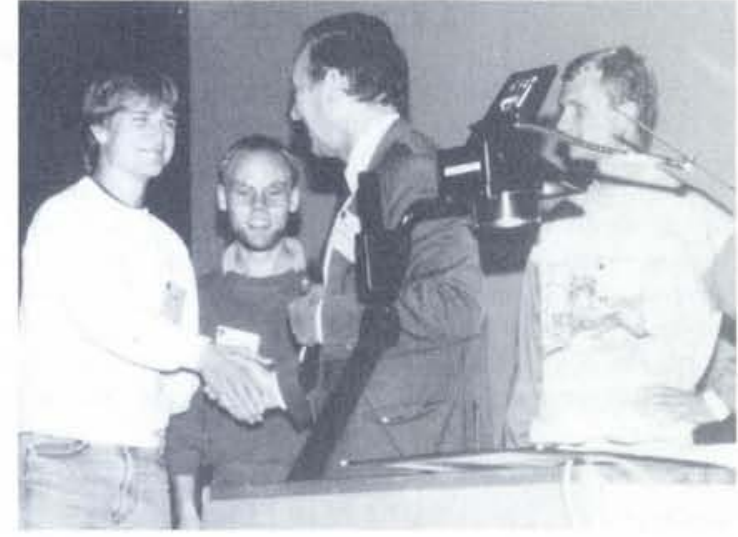

Members (right) of the Flying Circus being congratulated at EPS-8 for their enterprising displays (left) of physics in the streets of Copenhagen.

\section{Best Poster}

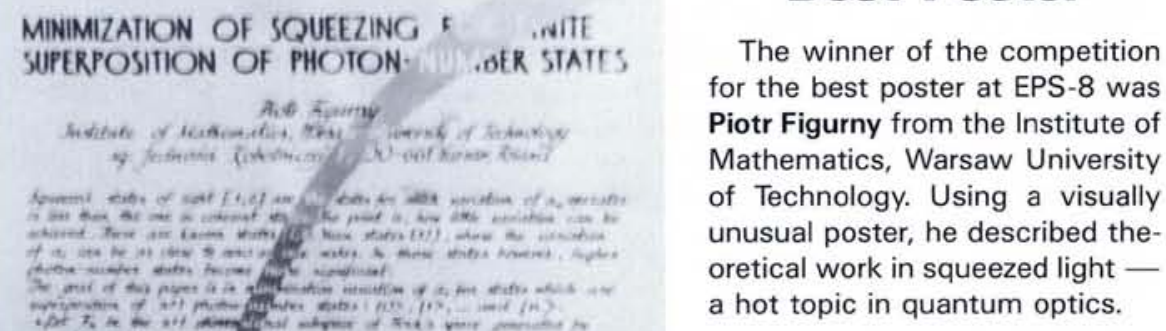

Piotr Figurny from Warsaw and his prizewinning poster "The Minimization of Squeezing for Finite Superimposition of Photon-Number States".

\section{Montanuniversität Leoben}

Ab sofort ist die Planstelle einer/eines

\section{Ordentlichen Universitätsprofessorin/Universitätsprofessors für Physik}

(Nachfolge von Prof. Bauer) zu besetzen. Gesucht wird eine/ein Physikerin/Physiker, die/der die Grundlagenausbildung für alle Studienrichtungen der Montanuniversität Leoben (Werkstoffwissenschaften, Markscheidewesen, Montanmaschinenwesen, Kunststofftechnik, Hüttenwesen, Gesteinshüttenwesen, Erdölwesen, Bergwesen, Angewandte Geowissenschaften) sicherstellen und im 2. Studienabschnitt eingerichtete werkstoffbezogene Ausbildungsbereiche z.B. "Werkstoffe der Elektronik" vertreten kann.

Die Forschungstätigkeit der/des Bewerberin/Bewerbers soll sich damit in den Rahmen der Montanuniversität Leoben sinnvoll einfügen. Bewerbungen mit den üblichen Unterlagen (Lebenslauf, Liste der wissenschaftlichen Veröffentlichungen, Beschreibung des beruflichen Werdeganges) sind bis zum 1. November 1990 an den

Rektor der Montanuniversität Leoben Franz-Josef-Strasse 18, A-8700 Leoben 